\title{
Research of the innovative development of the Russian Federation regions and its impact on the eco-friendliness of the economy based on neural network cluster analysis for the purpose of economic security
}

\author{
Sergey Yashin, Yuriy Trifonov, Andrey Sochkov, Sergey Borisov*, and Aleksander \\ Solovyev
}

Lobachevsky State University of Nizhny Novgorod, 23 Gagarin Avenue, 603022 Nizhny Novgorod, Russia

\begin{abstract}
This article is devoted to the assessment of innovative development of the Russian Federation regions using self-organizing Kohonen maps. The relevance of this paper is due to the need to develop various criteria for making decisions on state support for regions, the use of which will allow to conduct a comprehensive assessment of regional development. Its findings should serve as a reliable, high-quality source of information about the feasibility and type of support for a particular region. The study provides a justification for a set of indicators that are used in conducting cluster analysis. The methodology developed by the authors provides an opportunity to divide the regions into clusters, conduct their quantitative and qualitative analysis, and further predict the key indicators of the regions based on their belonging to different clusters. All this allows to study regional innovative development in dynamics. The authors draw a conclusion about the uneven innovative development of the Russian regions and the ambiguity of connections between the indicators of the share of organizations engaged in technological innovations and the degree of environmental friendliness of the economy. The findings of this study will be useful to public authorities when making decisions on the allocation of budgetary funds for the development of territories.
\end{abstract}

\section{Introduction}

Regional economic systems are an important part of building an effective national innovation system (NIS). They link the effective actions of individual enterprises and households with the effective functioning of the state, i.e. with the macroeconomic level. With the active involvement of states in the world economy, the relevance of regional development becomes even higher, since currently not only the internal state of the country's economy depends on the actions of the regions, but also the competitiveness of

\footnotetext{
${ }^{*}$ Corresponding author: ser211188@yandex.ru
} 
the national economy at the global level. Thus, the regions, as systems of the mesoeconomic level, connect into a single system the performance of the functioning of individual enterprises with ensuring the competitiveness of the national economy. Assessment of functioning of the economic and innovation system of regional economies, which is necessary for timely financial and other support from the state, becomes more relevant.

A significant number of studies have been devoted to assessing the level of innovative and economic development of regional economies and enterprises operating in their territories that carry out innovative activities, starting from the works of the famous Austrian economist J.A. Schumpeter [1-7].

The main disadvantage of the analyzed works is the fact that most of them tend to determine the integral indicator, which often gives a distorted idea of the research object due to the complexity of the selection of indicators and the choice of weight coefficients that determine the significance of a particular indicator. The authors of this study propose to use a set of indicators based on which the regions are ranked and the corresponding clusters are formed. This approach is useful for quantitative and qualitative analysis of regional processes, as well as for forecasting the characteristics of regions based on their belonging to a particular cluster.

The justification of the indicators that are used for analysis is one of the most difficult points of any research. In this case, we are talking about the indicators on the basis of which clusters of regions are formed. When studying innovation, the following two components should be assessed: innovation potential, i.e. the resources necessary for conducting innovation, and the innovation activity, i.e. the measures that are applied by the economic system (enterprise, region, state) to conduct innovation. Many existing methods consider only one of these components. In our opinion, a comprehensive analysis should consider both indicators that characterize the ability to carry out innovation, and indicators that show the actual implementation of innovation. Based on this, the authors selected five indicators that allow to provide a comprehensive assessment of the innovative development of the regions. The indicator of internal costs for research and development allows us to talk about the share of funds the company invests in the implementation of innovation. At the same time, this indicator alone is completely insufficient to assess the company's innovation, since costs in the economy must always be correlated with a positive economic effect. One of the indicators that can complement the costs of technological innovations and provide an answer to the question of the effectiveness of their use is the volume of innovative goods, works and services, which complements the first indicator and, according to the authors, must be used. An important regional indicator is the balance of export-import of technologies. The positive value of this indicator shows a high level of technological security in the region, therefore, this indicator was also considered by the authors. When importing products that do not meet various environmental standards, it is important to consider the eco-friendliness of the economy in the light of both the preservation of the health of citizens and possible economic sanctions on the part of individual countries. In particular, the importance of considering environmental factors is due to the introduction of a whole series of ISO 14000 environmental management standards. According to the authors, the share of organizations engaged in technological innovations is the most significant factor, since it is used as a target indicator of the program of technological development of the Russian Federation until 2024.

The authors believe that indicators of internal costs for research and development, the share of organizations engaged in technological innovation, characterize the innovative potential of the territory, while the volume of innovative products, goods and services, the balance of exports and imports of technologies and the eco-friendliness of the economy the innovative activity. 
Another argument in favor of the selected indicators is the fact that they are in the public domain on the portal of state statistics, which allows to analyze them on a regular basis and to verify the results obtained by other scientists if it is necessary to repeat the author's experiments.

The purpose of this paper is to study the level of innovative development of the regions of the Russian Federation and its impact on the eco-friendliness of the economy of these territories. To achieve this goal, it was necessary to solve the following tasks. First, the mathematical task of clustering regions was solved. Secondly, all the subjects of the Russian Federation were ranked according to the specific weight of organizations that implement innovations, and according to the eco-friendliness of regional economies. Thirdly, the relationship and the nature of the influence of these factors on each other were clarified. This task becomes especially urgent in the context of increasing interest in the issue of reducing greenhouse gas emissions and the construction of carbon landfills on the territory of the Russian Federation and a number of European countries [8]. In addition, based on the results obtained, it becomes possible to predict the key indicators of the regions, which makes it possible to assess their development in dynamics.

\section{Materials and methods}

The study of the innovative development of the regions of the Russian Federation was conducted on the basis of statistical data for 2017-2019, taken from the official website of the Federal State Statistics Service: https://rosstat.gov.ru/.

The following indicators were selected as the source data for the analysis: X1 - the share of organizations that carried out technological innovations in the total number of organizations surveyed (in percent); X2 - the volume of innovative goods, works, services (in percent); X3 - the balance of export-import of technologies (in billion rubles); X4 - ecofriendliness of the economy (billion rubles/thousand tons); X5 - internal expenditures on research and development (in billion rubles). Variable X1, which has the greatest weight among other factors in this study, is calculated using a new methodology and has been published on the specified website since 2017. The data for 2020 is not yet available in official sources, which explains the choice of the time period for the analysis.

In recent years, neural network techniques based on Kohonen's self-organizing maps (hereinafter - "SOM") are often used to study the activities of regions [9]. Thus, the work of Italian scientists [10] clusters and ranks 20 regions of Italy from 2005 to 2011 based on 12 indicators of well-being. The work of Chinese scientists [11] assesses the risk of natural disasters in China using the Kohonen SOM at the regional level using 28 indicators reflecting the danger of natural disasters. This work [12] carries out neural network modeling of the activities of the regions of the Russian Federation in the field of sports and physical education. According to the results of this activity for each period under review, all the subjects of the Russian Federation were divided into 5 groups, each of which was assigned a certain rank. The study revealed the uneven nature of the development of the regions of the Russian Federation in this area. The Kohonen map was modeled using the DEDUCTOR analytical package. When constructing the Kohonen SOM in the specified program, the final topological map, as a result of clustering, strongly depends on the initial settings of the process, which are set by the researcher. Topological maps differ from each other in the composition of clusters under different initial conditions. It is necessary to use the clustering quality criterion in order to determine the best partition. The partitioning in the noted paper [12] is carried out without using any criterion, and the initial conditions of the process are not specified.

The method used in this article is based on the paper [12], but it has been significantly improved in terms of eliminating the indicated shortcomings. Such indicators as "learning 
radius at the end of the process" and "learning rate at the end of the process"varied during clustering. To assess the objective division into clusters, the average and maximum quantization errors were tracked. The sum of their values for all clusters was calculated. The best partition was chosen according to its minimum value. Kohonen's SOMs allow us to solve the problem of ranking multidimensional objects, which are regions in the course of this analysis. The neural networks used make it possible to reduce the dimensionality of the initial data space by placing objects on a two-dimensional topological map. The DEDUCTOR analytical package also allows to visualize the results of the clustering process by marking the clusters with different colors. Data for analysis for 81 regions of the Russian Federation were collected with the exception of the Republic of Crimea, the city of Sevastopol, the Jewish Autonomous Region and the Chukotka Autonomous Okrug, for which there was no primary data on some indicators on the Rosstat website.

\section{Results and discussion}

The source data arrays were formed for each year of the considered time interval, after which they were subjected to the clustering procedure using the Kohonen SOM in the DEDUCTOR program. The following values were selected as the initial settings of the process: the partition into 5 fixed clusters and the dimension of the 9x9 cell topological map, which corresponds to one cell to one region, as well as the Gaussian neighborhood function. The parameters "number of epochs", "speed at the end of training", "radius at the end of training" varied in the course of computational experiments. Their values are shown in Table 1.

Table 1. Values of parameters used in the process of self-organization of Kohonen maps.

\begin{tabular}{|l|l|}
\hline DEDUCTOR program parameter name & Parameter values \\
\hline Number of epochs & $500 ; 1000$ \\
\hline Speed at the end of training & $0.005 ; 0.08 ; 0.14$ \\
\hline Radius at the end of training & $0.1 ; 1.2 ; 2$ \\
\hline
\end{tabular}

As a result, an ensemble of 18 neural networks was synthesized for each year's data. The average and maximum quantization errors across the clusters were monitored for each partition. The sums of the corresponding errors were calculated. The networks with the minimum value of these sums were chosen as the best clustering result. The topological maps of these partitions for the time intervals under study are shown in Figure 1.

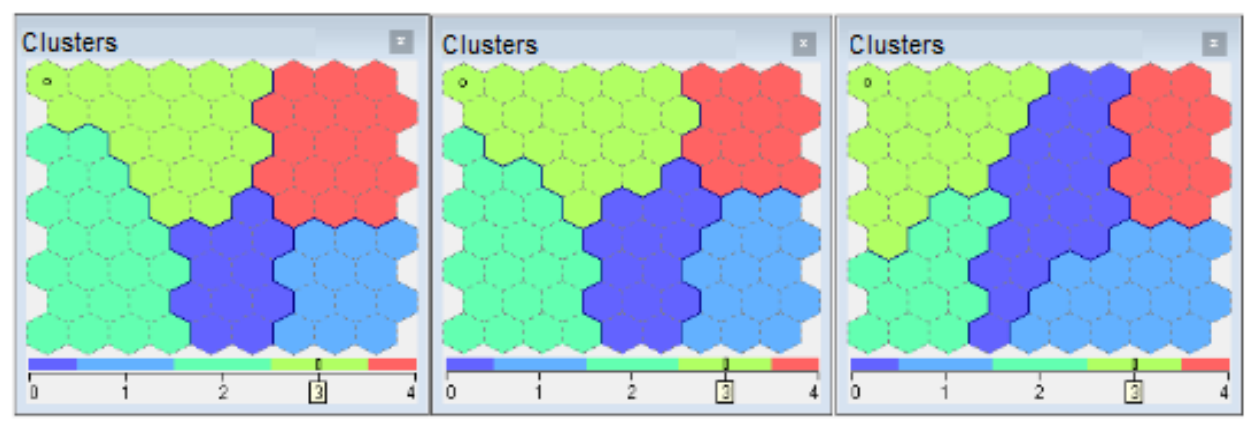

Source: developed by the authors

Fig. 1. Topological clustering maps for 2017-2019 data (arranged from left to right in ascending order of years). 
The average values for the clusters obtained were determined for each indicator (X1, $\mathrm{X} 2, \mathrm{X} 3, \mathrm{X} 4, \mathrm{X} 5$ ). These statistical characteristics for each considered time interval are given in Table 2, which also shows their average values for the Russian Federation as a whole.

Table 2. Average values of the studied indicators by clusters for 2017-2019.

\begin{tabular}{|l|c|c|c|c|c|}
\hline \multicolumn{7}{|c|}{ Indicator } & X1 & X2 & X3 & X4 & X5 \\
\hline \multicolumn{7}{|c|}{$\mathbf{2 0 1 7}$} \\
\hline Cluster 0 & 15.180 & 8.170 & 0.001 & 6.175 & 4.460 \\
\hline Cluster 1 & 19.992 & 17.285 & -0.096 & 6.183 & 8.192 \\
\hline Cluster 2 & 11.729 & 0.971 & -0.225 & 7.283 & 1.233 \\
\hline Cluster 3 & 20.255 & 2.736 & -0.076 & 11.464 & 3.875 \\
\hline Cluster 4 & 30.817 & 9.475 & 0.01 & 33.492 & 62.568 \\
\hline $\begin{array}{l}\text { Russian } \\
\text { Federation }\end{array}$ & 20.800 & 7.200 & -1.530 & 4.557 & 12.582 \\
\hline \multicolumn{7}{|c|}{$\mathbf{2 0 1 8}$} \\
\hline Cluster 0 & 15.633 & 7.578 & -0.126 & 9.548 & 6.793 \\
\hline Cluster 1 & 19.629 & 15.693 & -3.060 & 6.648 & 7.306 \\
\hline Cluster 2 & 11.452 & 1.142 & -0.401 & 12.151 & 1.075 \\
\hline Cluster 3 & 20.922 & 2.828 & -3.040 & 7.304 & 5.183 \\
\hline Cluster 4 & 30.378 & 9.044 & 0.498 & 48.064 & 81.753 \\
\hline $\begin{array}{l}\text { Russian } \\
\text { Federation }\end{array}$ & 19.800 & 6.500 & -1.285 & 5.275 & 12.694 \\
\hline \multicolumn{7}{|c|}{$\mathbf{2 0 1 9}$} & & \\
\hline Cluster 0 & 21.800 & 4.218 & -1.712 & 7.082 & 5.894 \\
\hline Cluster 1 & 24.132 & 11.253 & 4.527 & 8.334 & 11.378 \\
\hline Cluster 2 & 13.033 & 5.533 & -0.267 & 4.860 & 5.895 \\
\hline Cluster 3 & 11.855 & 1.073 & -3.424 & 10.482 & 1.848 \\
\hline Cluster 4 & 31.900 & 5.550 & -1.072 & 63.702 & 119.878 \\
\hline $\begin{array}{l}\text { Russian } \\
\text { Federation }\end{array}$ & 21.600 & 5.300 & -1.052 & 5.482 & 14.010 \\
\hline
\end{tabular}

Source: developed by the authors

Then, based on these values, the clusters were subjected to a ranking procedure. The cluster with the maximum average value of the X1 indicator was selected of the five clusters of the 2017 partition, which was assigned a rank of 1 . All the regions that make up this cluster received the corresponding rank, listed in the column "2017 (X1)" of Table 3. Then "cluster 3" was selected, in which the average value of the X1 indicator was slightly less. It was assigned a rank of 2, and all the regions included in it were assigned this rating. The remaining clusters were ranked in descending order of the average value of the X1 indicator, and all regions were assigned the corresponding rank listed in Table 3.

This procedure was repeated for the 2018 and 2019 data. In addition, according to a similar scheme, the clusters and their constituent regions were ranked according to the average value of the X4 indicator. All the results obtained are listed in Table 3.

Table 3. Rating of innovative development of regions of the Russian Federation

\begin{tabular}{|r|l|r|r|r|r|r|r|r|c|c|}
\hline & & \multicolumn{2}{|c|}{2017} & \multicolumn{2}{|c|}{2018} & \multicolumn{2}{c|}{$\mathbf{2 0 1 9}$} & & \\
\cline { 3 - 8 } No. & Regions & X1 & X4 & X1 & X4 & X1 & X4 & 2017-2019 (X1) & 2017-2019 (X4) \\
\hline 1 & Moscow & 1 & 1 & 1 & 1 & 1 & 1 & 1 & 1 \\
\hline 2 & St. Petersburg & 1 & 1 & 1 & 1 & 1 & 1 & 1 & 1 \\
\hline 3 & Kaluga Region & 2 & 2 & 1 & 1 & 3 & 4 & 1 & 2 \\
\hline 4 & Lipetsk Region & 1 & 1 & 2 & 5 & 3 & 4 & 1 & 3 \\
\hline 5 & Moscow Region & 1 & 1 & 1 & 1 & 1 & 1 & 1 & 1
\end{tabular}


Table 3. Continued

\begin{tabular}{|c|c|c|c|c|c|c|c|c|c|}
\hline 6 & $\begin{array}{l}\text { Nizhny Novgorod } \\
\text { Region }\end{array}$ & 1 & 1 & 1 & 1 & 2 & 3 & 1 & 1 \\
\hline 7 & Primorsky Territory & 2 & 2 & 2 & 5 & 2 & 3 & 1 & 3 \\
\hline 8 & Sverdlovsk Region & 1 & 1 & 2 & 5 & 3 & 4 & 1 & 3 \\
\hline 9 & Tomsk Region & 2 & 2 & 2 & 5 & 1 & 1 & 1 & 2 \\
\hline 10 & Chelyabinsk Region & 1 & 1 & 2 & 5 & 1 & 1 & 1 & 2 \\
\hline 11 & Chuvash Republic & 1 & 1 & 3 & 4 & 2 & 3 & 1 & 2 \\
\hline 12 & Belgorod Region & 3 & 4 & 3 & 4 & 2 & 3 & 2 & 4 \\
\hline 13 & Vladimir Region & 1 & 1 & 4 & 3 & 3 & 4 & 2 & 2 \\
\hline 14 & Voronezh Region & 4 & 5 & 2 & 5 & 2 & 3 & 2 & 5 \\
\hline 15 & Kirov Region & 4 & 5 & 2 & 5 & 2 & 3 & 2 & 5 \\
\hline 16 & $\begin{array}{l}\text { Krasnoyarsk } \\
\text { Territory }\end{array}$ & 2 & 2 & 1 & 1 & 4 & 5 & 2 & 2 \\
\hline 17 & Leningrad Region & 2 & 2 & 1 & 1 & 5 & 2 & 2 & 1 \\
\hline 18 & Penza Region & 1 & 1 & 5 & 2 & 2 & 3 & 2 & 1 \\
\hline 19 & Perm Territory & 3 & 4 & 3 & 4 & 2 & 3 & 2 & 4 \\
\hline 20 & Republic of Adygea & 4 & 5 & 2 & 5 & 2 & 3 & 2 & 5 \\
\hline 21 & $\begin{array}{l}\text { Republic of } \\
\text { Mordovia }\end{array}$ & 3 & 4 & 3 & 4 & 2 & 3 & 2 & 4 \\
\hline 22 & Republic of Tatarstan & 3 & 4 & 3 & 4 & 2 & 3 & 2 & 4 \\
\hline 23 & Rostov Region & 3 & 4 & 4 & 3 & 1 & 1 & 2 & 2 \\
\hline 24 & Samara Region & 3 & 4 & 3 & 4 & 2 & 3 & 2 & 4 \\
\hline 25 & Tula Region & 3 & 4 & 3 & 4 & 2 & 3 & 2 & 4 \\
\hline 26 & Ulyanovsk Region & 3 & 4 & 3 & 4 & 2 & 3 & 2 & 4 \\
\hline 27 & $\begin{array}{l}\text { Khabarovsk } \\
\text { Territory }\end{array}$ & 3 & 4 & 3 & 4 & 2 & 3 & 2 & 4 \\
\hline 28 & Yaroslavl Region & 1 & 1 & 3 & 4 & 3 & 4 & 2 & 3 \\
\hline 29 & Arkhangelsk Region & 3 & 4 & 3 & 4 & 4 & 5 & 3 & 5 \\
\hline 30 & Kamchatka Territory & 1 & 1 & 4 & 3 & 5 & 2 & 3 & 1 \\
\hline 31 & Kurgan Region & 2 & 2 & 4 & 3 & 3 & 4 & 3 & 3 \\
\hline 32 & Magadan Region & 2 & 2 & 4 & 3 & 3 & 4 & 3 & 3 \\
\hline 33 & Murmansk Region & 2 & 2 & 5 & 2 & 3 & 4 & 3 & 2 \\
\hline 34 & Novgorod Region & 2 & 2 & 4 & 3 & 3 & 4 & 3 & 3 \\
\hline 35 & Mari El Republic & 3 & 4 & 5 & 2 & 2 & 3 & 3 & 3 \\
\hline 36 & Ryazan Region & 4 & 5 & 4 & 3 & 2 & 3 & 3 & 4 \\
\hline 37 & Smolensk Region & 2 & 2 & 5 & 2 & 3 & 4 & 3 & 2 \\
\hline 38 & Tambov Region & 4 & 5 & 2 & 5 & 4 & 5 & 3 & 5 \\
\hline 39 & Tver Region & 2 & 2 & 4 & 3 & 3 & 4 & 3 & 3 \\
\hline 40 & Tyumen Region & 5 & 3 & 3 & 4 & 2 & 3 & 3 & 3 \\
\hline 41 & Udmurt Republic & 4 & 5 & 3 & 4 & 2 & 3 & 3 & 4 \\
\hline 42 & Altai Territory & 2 & 2 & 4 & 3 & 5 & 2 & 4 & 2 \\
\hline 43 & Astrakhan Region & 5 & 3 & 1 & 1 & 5 & 2 & 4 & 1 \\
\hline 44 & Bryansk Region & 4 & 5 & 5 & 2 & 3 & 4 & 4 & 4 \\
\hline 45 & Volgograd Region & 2 & 2 & 5 & 2 & 5 & 2 & 4 & 1 \\
\hline 46 & $\begin{array}{l}\text { Kabardino-Balkar } \\
\text { Republic }\end{array}$ & 2 & 2 & 5 & 2 & 5 & 2 & 4 & 1 \\
\hline 47 & Krasnodar Territory & 3 & 4 & 3 & 4 & 5 & 2 & 4 & 3 \\
\hline 48 & Kursk Region & 4 & 5 & 3 & 4 & 4 & 5 & 4 & 5 \\
\hline 49 & Novosibirsk Region & 4 & 5 & 4 & 3 & 3 & 4 & 4 & 4 \\
\hline 50 & Omsk Region & 2 & 2 & 4 & 3 & 5 & 2 & 4 & 2 \\
\hline 51 & Orenburg Region & 5 & 3 & 2 & 5 & 4 & 5 & 4 & 5 \\
\hline 52 & Pskov Region & 2 & 2 & 5 & 2 & 5 & 2 & 4 & 1 \\
\hline 53 & Altai Republic & 2 & 2 & 5 & 2 & 5 & 2 & 4 & 1 \\
\hline 54 & $\begin{array}{l}\text { Republic of } \\
\text { Bashkortostan }\end{array}$ & 4 & 5 & 4 & 3 & 3 & 4 & 4 & 4 \\
\hline 55 & Republic of Buryatia & 2 & 2 & 5 & 2 & 5 & 2 & 4 & 1 \\
\hline 56 & $\begin{array}{l}\text { Republic of } \\
\text { Ingushetia }\end{array}$ & 2 & 2 & 5 & 2 & 5 & 2 & 4 & 1 \\
\hline
\end{tabular}


Table 3. Continued

\begin{tabular}{|c|c|c|c|c|c|c|c|c|c|}
\hline 57 & $\begin{array}{l}\text { Republic of Sakha } \\
\text { (Yakutia) }\end{array}$ & 2 & 2 & 4 & 3 & 5 & 2 & 4 & 2 \\
\hline 58 & Saratov Region & 2 & 2 & 4 & 3 & 5 & 2 & 4 & 2 \\
\hline 59 & $\begin{array}{l}\text { Khanty-Mansijsk } \\
\text { Autonomous District } \\
\text { Yugra }\end{array}$ & 5 & 3 & 1 & 1 & 5 & 2 & 4 & 1 \\
\hline 60 & Amur Region & 5 & 3 & 5 & 2 & 5 & 2 & 5 & 2 \\
\hline 61 & Vologda Region & 5 & 3 & 5 & 2 & 3 & 4 & 5 & 3 \\
\hline 62 & $\begin{array}{l}\text { Trans-Baikal } \\
\text { Territory }\end{array}$ & 5 & 3 & 5 & 2 & 5 & 2 & 5 & 2 \\
\hline 63 & Ivanovo Region & 5 & 3 & 5 & 2 & 3 & 4 & 5 & 3 \\
\hline 64 & Irkutsk Region & 5 & 3 & 5 & 2 & 5 & 2 & 5 & 2 \\
\hline 65 & Kaliningrad Region & 5 & 3 & 5 & 2 & 5 & 2 & 5 & 2 \\
\hline 66 & $\begin{array}{l}\text { Karachay-Cherkess } \\
\text { Republic }\end{array}$ & 5 & 3 & 5 & 2 & 5 & 2 & 5 & 2 \\
\hline 67 & Kemerovo Region & 5 & 3 & 5 & 2 & 5 & 2 & 5 & 2 \\
\hline 68 & Kostroma Region & 4 & 5 & 5 & 2 & 5 & 2 & 5 & 3 \\
\hline 69 & $\begin{array}{l}\text { Nenets Autonomous } \\
\text { District }\end{array}$ & 5 & 3 & 5 & 2 & 5 & 2 & 5 & 2 \\
\hline 70 & Orel Region & 5 & 3 & 5 & 2 & 3 & 4 & 5 & 3 \\
\hline 71 & Republic of Dagestan & 5 & 3 & 5 & 2 & 5 & 2 & 5 & 2 \\
\hline 72 & $\begin{array}{l}\text { Republic of } \\
\text { Kalmykia }\end{array}$ & 5 & 3 & 5 & 2 & 5 & 2 & 5 & 2 \\
\hline 73 & Republic of Karelia & 5 & 3 & 5 & 2 & 5 & 2 & 5 & 2 \\
\hline 74 & Komi Republic & 5 & 3 & 5 & 2 & 5 & 2 & 5 & 2 \\
\hline 75 & $\begin{array}{l}\text { Republic of North } \\
\text { Ossetia-Alania }\end{array}$ & 5 & 3 & 5 & 2 & 5 & 2 & 5 & 2 \\
\hline 76 & Tyva Republic & 5 & 3 & 5 & 2 & 5 & 2 & 5 & 2 \\
\hline 77 & $\begin{array}{l}\text { Republic of } \\
\text { Khakassia }\end{array}$ & 5 & 3 & 5 & 2 & 5 & 2 & 5 & 2 \\
\hline 78 & Sakhalin Region & 5 & 3 & 5 & $\frac{2}{2}$ & 5 & $\frac{2}{2}$ & 5 & $\frac{2}{2}$ \\
\hline 79 & Stavropol Territory & 4 & 5 & 5 & 2 & 4 & 5 & 5 & 4 \\
\hline 80 & Chechen Republic & 5 & 3 & 5 & 2 & 5 & 2 & 5 & 2 \\
\hline 81 & $\begin{array}{l}\text { Yamalo-Nenets } \\
\text { Autonomous District }\end{array}$ & 3 & 4 & 5 & 2 & 5 & 2 & 5 & 2 \\
\hline
\end{tabular}

Source: developed by the authors

The final ranks were determined to assess the innovative development of the regions of the Russian Federation for the entire period under consideration. Their calculation based on the data of the ranking of objects by the average value of the indicator X1 was carried out according to the following algorithm. In the first step, the sum of the ranks of each region for 3 years was determined, for example, the rank of the Kaliningrad region was 5 for all three years studied, therefore, the sum was 15 . In the second step, all the regions were grouped according to their sum of ranks. The first group includes territories with the sum of ranks from 3 to 6 , the second - from 7 to 8 , the third - from 9 to 10 , the fourth - from 11 to 12 , and the fifth - from 13 to 15 . The final rank of the region for the three years under consideration, entered in table 3, corresponds to the number of the group in which it fell. The calculation of the final ranks based on the X4 indicator was carried out according to a similar method and entered in the corresponding column of Table 3.

Let's consider the typology of the groups obtained based on the X1 indicator. The first group includes 11 regions-leaders of innovative development in the country. Four subgroups can be distinguished among them. The first subgroup consists of territories with stable dynamics, i.e. their rank does not change over time. Typical representatives of the subgroup: Moscow and the Moscow region, as well as St. Petersburg, whose rating was equal to one for all three years. The second subgroup consists of regions with positive dynamics, the rating of which has been growing throughout the period under review. The 
Tomsk region can be cited as an example. The third subgroup includes regions with unstable dynamics, whose rating rises and falls. The Chelyabinsk region can be noted as a typical representative. The last subgroup is made up of regions with negative dynamics, the rating of which is constantly falling, for example, the Sverdlovsk region. If the current trend continues, such regions risk losing their positions among the leaders.

The second group consists of territories with transitional dynamics. Three subgroups can be distinguished among them. The first subgroup includes regions striving for the group of leaders and showing positive dynamics, for example, the Republic of Mordovia. The second subgroup is made up of regions with unstable dynamics, such as the Penza region and the Leningrad region. The third subgroup includes regions with negative dynamics, moving from the group of leaders to the group of middle peasants, while maintaining this trend. The Yaroslavl region can be noted as an example.

The third group consists of the "middle" territories. Three subgroups can be distinguished among them, the typologies of which are similar to the previous ones. As an example of the region improving its position, we can mention the Udmurt Republic. The Smolensk Region demonstrates unstable dynamics relative to the average level and the Kamchatka Territory is losing ground over the past three years.

The fourth group is also a transitional one, only transitions are made between the groups of middle regions and outsiders. There are three typologies of regions in this group. The Novosibirsk region gives an example of positive dynamics. Unstable innovative development is demonstrated, for example, by the Astrakhan region. Altai Territory has a negative dynamics and the risk of falling into outsiders.

The fifth group consists of outsider territories. This group contains all the above typologies. As an example of a region with positive dynamics, we can mention the Orel Region, which improved its rating to the third rank in 2019. For example, the Kaliningrad region demonstrates stable dynamics, but with a low level of indicators. Some regions are trying to improve their position, but their activities and results are clearly unstable. An example is the Stavropol Territory. The last subgroup consists of regions that showed an average level of indicators of innovative development in 2017, but later their values decreased, for example, the Yamalo-Nenets Autonomous District.

The development of innovative economies of the constituent entities of the Russian Federation should contribute, among other things, to the improvement of the environmental situation in these regions. To assess the level of environmental friendliness of the territory's economy, the X4 indicator was used in this study, a high value of which characterizes a developed, balanced and "green" economy. As noted above, the ranking of regions was carried out on the basis of this indicator (see Table 3). Comparison of the above rating with the rating based on the $\mathrm{X} 1$ indicator allows us to assess the impact of the factor of innovative development of the region on its environmental situation.

The analysis of Table 3 shows that the leaders of innovative development in the country, demonstrating the stability of high indicators in this area, also have a high rating in terms of the environmental friendliness of the economy. We can note such regions as Moscow and the Moscow region, St. Petersburg and the Nizhny Novgorod region, which are the leaders of both ratings.

Another typical group is made up of industrially developed regions that demonstrate good indicators of innovative development (they have a rank of 2 in the rating according to $\mathrm{X} 1$ ), but their position in the rating of "eco-friendliness of the economy" has a rank of 4 out of 5. This can be explained by the fact that the developed industry of these territories produces a large amount of emissions of pollutants, which worsens their position in the "environmental" rating, while the innovative activities carried out in the region do not yet provide the necessary results for "greening" the economy, i.e. these regions need to continue working on innovations that improve the environment. As an example, we can 
note such an industrially developed region as the Samara Region, which demonstrates the dynamics of the rank in X1 $(3 ; 3 ; 2)$, and in X4 - $(4 ; 4 ; 3)$. In this example, we can notice the correlation of the given ranks, i.e. an improvement in the position in innovative development leads to an improvement in the position in the environmental rating.

The third typical group again confirms the thesis that the level of innovative development of a region largely determines its "green" rating. Most of the regions in this group have the same final rank 3 in terms of ratings based on X1 and based on X4. As an example, we can mention the Novgorod and Tver Regions.

The last two typical groups of territories with final ranks 4 and 5 in terms of innovative development have ranks 1 and 2, respectively, in terms of environmental friendliness of the economy. This can be explained by the fact that on the one hand, the more active the innovation activity in the region, the better the environment, and on the other hand, these groups are mainly specific regions with good ecology due to their geographical location, but with a low level of development of the production sector of the economy. Examples include the Republic of Altai and the Kabardino-Balkarian Republic (with ratings of 4 and 1 at $\mathrm{X} 1$ and $\mathrm{X} 4$, respectively), as well as the Republic of Karelia and the Kaliningrad Region (with ratings of 5 and 2 at X1 and X4, respectively).

\section{Conclusions}

According to the authors, the most significant results of the study are:

1. Data presented in Tables 2 and 3 shows a significant unevenness of regional innovation development in the Russian Federation. There are a few regions that are leaders in innovative development and a large group of outsider regions. Moreover, as we can see, the gap between them is significant. Considering that the comprehensive innovative development of a country is possible only with the growth of all its constituent regional economies, it is necessary to develop federal support measures for outsider regions, taking into account their characteristics. The specifics of these regions can be reflected in their geographical location, climatic conditions, and in the following elements of regional infrastructure: the type of industry; proximity to major federal centers, such as Moscow and St. Petersburg, the specifics of the formation of the regional budget, etc.

2. There is an ambiguous relationship between the innovative development of the region and the environmental friendliness of its economy. This is evidenced by the significant difference in the ratings based on the indicators X1 and X4. Thus, the coincidence of these ratings, which means a simultaneous high innovative development and serious attention on the part of regional enterprises to the issues of environmental protection and ecology, is observed only among the leading regions. When forming state policy and deciding on the allocation of federal funds to the regions, both ratings should be taken into account. It is necessary to analyze the advanced experience of the leading regions and pass it on to the rest of the territories. It is also necessary to allocate funds and take organizational measures to support the development of regions with a low level of eco-friendly economy by stimulating their innovative development, since the authors believe that an innovative economy should contribute to improving the level of ecology.

\section{Acknowledgments}

The study was carried out within the framework of the basic part of the state assignment of the Ministry of Education and Science of the Russian Federation, project 0729-2020-0056 "Modern methods and models of diagnostics, monitoring, prevention and overcoming of 
crisis phenomena in the economy in the context of digitalization as a way to ensure the economic security of the Russian Federation"

\section{References}

1. T. Moiseeva, Y. Myatishkin, SHS Web of Conferences, 94 (2020)

2. E.von Hippel, Jeroen de Jong, Open. Distributed and User-Centered: Towards a Paradigm Shift in Innovation Policy (2010)

3. A. M. Nosonov, Regionology, 4(89) (2014)

4. I. E. Ilina, E. N. Zharova, E. V. Agamirova, A. S. Kamenskiy, Regionology, 26(2) (2018)

5. E. P. Garmashova, A. M. Drebot, Russian Journal of Innovation Economics, 10(3) (2020)

6. S. N. Yashin, N. I. Yashina, Yu. V. Zakharova, O. S. Boronin, Journal of Creative Economy, 13(11) (2019)

7. S. N. Yashin, S. A. Borisov, Russian Journal of Innovation Economics, 10(2) (2020)

8. Decree of the President of the Russian Federation, 76. On measures to implement the State Scientific and Technical Policy in the field of environmental development of the Russian Federation and climate change (2021) https://minobrnauki.gov.ru

9. T. Kohonen, E. Oja, O. Simula, A. J. E. Visa, J. Kangas, Proceedings of the Institute of Electrical and Electronics Engineers, 84 (1996)

10. O. A. Carboni, P. Russu, Social Indicators Research, 122 (2015)

11. N. Chen, L. Chen, Y. Ma, A. Chen, International Journal of Disaster Risk Reduction, 33 (2019)

12. E. N. Letiagina, V. I. Perova, E. A. Orlova, ICISTIS. Atlantis Press, 11 (2020) 